\title{
The Use of Pictures as Media to Improve Students' Reading Comprehension
}

\author{
Mukhamad Ardiansyah Efendi \\ Universitas Muhammadiyah Malang \\ E-mail: ardiansyah@yahoo.com
}

Received: July 10, 2018

Accepted: August 17, 2018

Published: August 31, 2018

Doi: http://dx.doi.org/10.30587/jetlal.v2i2.2467

\begin{abstract}
Reading is an important skill for developing second language competence. The success of a learning a second language is by taking the power of reading. In the classroom, we will face many techniques applied to the students under the expectation that they are able to or easy to understand the lesson. For a teacher, it is necessary to find new teaching media to overcome the problems and not to forget to motivate the students. In this paper, the writer wants to know the effect of picture as a media to improve students' reading comprehension. The purpose of this research is to find out whether the use of pictures can improve students' reading comprehension or not. To make the students easily understand about the reading material, teacher needs to have a teaching media. Then, the writer chooses visual media that is picture to increase students' reading mastery. Pictures are considered as the best media in teaching reading because using picture as a teaching media are able to give the students a clear illustration regarding the correlated topics in texts, tell the students what is going on, and what are the persons in the text are talking about. Nowadays, the pictures and the technologies are becoming more and more advanced. In this decade, we can already materialize a more advanced picture that added by motion and sounds by using simple applications provided in home personal computer. Moreover, the students now are quite used and interested to apply any high tech media.

Based on the result of discussion, it can be concluded that pictures are theoretically can be a good media to help the students enhancing their reading comprehension. Therefore in this view, it is justifiable to hypothetically conclude that using pictures for strengthening students' visual sense can help them to understand a text.
\end{abstract}

Keywords: media, picture, reading comprehension.

\section{INTRODUCTION}

Reading comprehension is the process of making meaning of the text (Woolley, 15: 2011). Rosenblatt (cf. Moreillon, 155: 2007) also defines reading as an interaction between the reader, the author, and the text which will produce the meaning during the process. Through reading the students learn to grasp vocabularies, spell words precisely, recognize various grammar patterns, and identify how a good text is structured.

Reading has several benefits. According to Listiyanto (in Aizid, 2011:25), benefits of reading are: 1) Reading can provide a number of information and knowledge which is very useful in daily practice, 2) reading makes a person can communicate with thoughts, messages, and suggests the notion of big-thinking of the whole world, 3 ) reading can follow the development of science and technology, 4) reading can find out the big events in the history, civilization, and culture of a nation, 5) reading can solve the problems of life and leads a person into a smart, clever, and being nice. Hence, reading is very important.

It is undoubted that the current English teaching and learning process encounter several issues on efficiency so that students cannot obtain enough understanding toward the material. Despite the fact that there have been already dozens media being implemented in classroom, either the lack of teaching capability and incompatible teaching media done by the teacher could be one of many factors causing this issue emerges. Hence, it is significant to study various teaching media in classroom in order to find the sought result.

The media that are often being used is picture, a visual device that can aid students to enhance their reading skill (Broughton, 107: 1980). It can be in the form of flash card, photograph, illustration, cue cards, etc. Furthermore, Levie of Lentz (in Arsyad, 2009) states that there are four functions of visual media, namely attention function, affective function, cognitive function, and compensators function. Indeed, a better outcome in reading is highly expected by using picture in teaching reading.

According Susilana (2007:9) the advantages of using media are: 1) Clarify a message that is not too verbal. 2) Overcoming the limitations of space, time, energy, and power of the senses. 3) Creates a passion to learn, more direct interaction between students and learning resources. 4) Allows children to learn independently according to their talents 
and visual, auditory and kinesthetic ability. 5) Giving the same stimulation, equalizing the experience, and give the same perception. Therefore, by using media in the classroom, students can more understand the reading material easily.

The writer believes that it is the obligation for every teacher to find and implement the best teaching media that is effective and compatible for both teacher and students. Based on those issues and explanation above, it is reasonable for conducting research to find out whether pictures can effectively improve students' reading comprehension or not.

\section{DISCUSSION}

Before starting the discussion, some problems need to be stated. What is actually reading and what makes it important? Why pictures are considered as best media in teaching reading? And do we really need to do all of this? For getting the answer and specifying the conclusion, let's just move on to the first issue.

Fist thing first, reading is generally defined as an act to see and understand the meaning of written text. However, every definition made by another scholar usually goes similar, take an instance to the definition stated by Rosenblatt and Woolley in the previous chapter. Let's underline the word "see" and the phrase "understand the meaning" in the definition above. We can say that reading include visual sense as the main instrument and create understanding as the primary aim in the end of the process.

There are two main reasons why reading is essential. First of all, during the process, the students learn to grasp vocabularies, spell words precisely, recognize various grammar patterns, and identify how a good text is structured. In other words, reading is strengthening the other three skills in English. Therefore, reading comprehension is, perhaps, the most fundamental one among the three other skills since it leads them to have better comprehension in listening, speaking, and writing. Second of all, reading is actually can be very challenging when the students have to encounter unfamiliar, technical, and complex content. The readers can decode the words, but have not developed sufficient skills to comprehend the underlying, deeper meaning of the sentences, the paragraph, and the entire text (McNamara, 11: 2012). In brief, reading is quite significant so that we must strive to create effective teaching for helping the students master it.

To make the students easily understand about the reading material, teacher needs to have a teaching media. In education, media is tool for communication between teachers and students. Media can also be interpreted as mediator or introductory message from sender to receiver. The word media comes from the word of medium, which literally means as an intermediary or introductory message from the sender to the receiver of the message (Sadiman, 2002: 6). Moreover, there are three types of media those are audio, visual, and audio-visual media, but the writer consider choosing visual media to enhance the students' reading comprehension. Then, visual media is the media that enable learners to gain the information or knowledge through their eyes sense (Kasbollah in Sabilah 2001: 31). So that, visual media is the media which only rely on senses of sight in a visual form. Some examples of visual media are picture file, flash cards, chart, etc.

Under the stated reasons above, the writer chooses to use picture as the best visual media for teaching reading. Fisher said in his book, Essential Reading on Comprehension (p. 32, 2009), "A picture is worth a thousand words" is particularly relevant as they manoeuvre their way through the informational maze of learning from a text. Not to mention, using picture as a teaching media are able to give the students a vivid illustration regarding the correlated topics in texts, tell the students what is going on, and what are the persons in the text are talking about.

Before implementation of the media picture in the class, the teacher gives a post test first to the students in order to know the students' reading capabilities. Then, the teacher give them appropriate material. For examples; 1) students are given a narrative text telling about the story of Tintin's Adventure which is added with several pictures describing the sequences of events happening in the story, 2) students are given a material about making an appointment which is added with pictures showing two persons making an appointment to have a date. Logically, any beginning learners will find difficulties in understanding the text and will find it easier by aided with illustration. After the implementation of the media picture, the teacher gives them a post test to the students in order to know whether the media picture can increase their reading ability or not.

Some says that pictures as a media are already invented years ago hence it is redundant to conduct a research on it. However, some "new" idea can be invented by using a different term for the every same approach in teaching reading (Ediger, 356: 2000). Despite the fact of its age, the pictures and the technologies are becoming more and more advanced. A long time ago, the use of pictures were too old-fashioned, it was just a piece of paper, nothing more. In this decade, we can already materialize a more advanced picture that added by motion and sounds by using simple applications provided in home pc. Moreover, the students now are quite used and interested to apply any high tech media (Beach, 2012).

The main issue to be discussed here is whether or not by using pictures as the media can significantly improve student's reading comprehension. Under the elaborations above, it is vividly tangible that pictures are theoretically can be a good media to help the students enhancing their reading comprehension. Therefore in this view, it is justifiable to hypothetically conclude that using pictures for strengthening students' visual sense can help them to understand a text.

\section{CONCLUSION}

Based on the discussion, it can be conclude that reading is an act to see and understand the meaning of written text. Moreover, reading as an interaction between the reader, the author, and the text which will produce the meaning 
during the process. Therefore, we can say that reading include visual sense as the main instrument and create understanding as the primary aim in the end of the process. Reading is important because of two reasons. First, during the process, the students learn to grasp vocabularies, spell words precisely, recognize various grammar patterns, and identify how a good text is structured. Second, reading is a challenging activity when the students have to encounter unfamiliar, technical, and complex content by decoding the words, but have not developed sufficient skills to comprehend the underlying, deeper meaning of the sentences, the paragraph, and the entire text. In brief, reading is quite significant so that we must strive to create effective teaching for helping the students master it.

To make the students easily understand about the reading material, teacher needs to have a teaching media. In education, media is tool for communication between teachers and students. Then, the writer chooses visual media that is picture to increase students' reading mastery. Pictures are considered as the best media in teaching reading because using picture as a teaching media are able to give the students a vivid illustration regarding the correlated topics in texts, tell the students what is going on, and what are the persons in the text are talking about.

Nowadays, the pictures and the technologies are becoming more and more advanced. In this decade, we can already materialize a more advanced picture that added by motion and sounds by using simple applications provided in home personal computer. Moreover, the students now are quite used and interested to apply any high tech media.

The main issue to be discussed here is whether or not by using pictures as the media can significantly improve student's reading comprehension. Under the elaborations above, it is vividly tangible that pictures are theoretically can be a good media to help the students enhancing their reading comprehension. Therefore in this view, it is justifiable to hypothetically conclude that using pictures for strengthening students' visual sense can help them to understand a text.

\section{REFERENCES}

Aizid, Rizem. 2011. Bisa Baca Secepat Kilat. Jogjakarta: Buku Biru.

Arsyad, Azhar. 2009. Media Pembelajaran. Jakarta: Raja Grafindo Persada.

Beach, Richard, Amanda Haertling, Allen Webb. 2012. Teaching to Exceed the English Language Arts Common Core State Standard. New York: Rouledge Taylor \& Francis Group.

Broughton, Geoffrey. 1980. Teaching English as a Foreign Language. New York: Routledge Education Books.

Ediger, Marlow. 2000. Teaching Reading Successfully. New Delhi: Discovery Publish House.

Sabilah, Fardini. 2001. A Closer Look at the Use of Media in English Classes at Elementary School. An Unpublish Research Report. Malang.

Sadiman S, Arief .et al. 2010. Media Pendidikan: Pengertian, Pengembangan, dan Pemanfaatannya. Jakarta: RajaGrafindo Persada.

Susilana, and Riyana. 2007 Media Pembelajaran. Bandung: CV Wacana Prima.

Moreillon, Judi. 2007. Collaborative Strategy for Teaching Reading Comprehension. USE: American Library Association.

McNamara, Danielle. 2012. Reading Comprehension Strategies. New York: Psychology Press.

Lapp, Diane and Douglas Fisher. 2009. Essential Reading on Comprehension. International Reading Association.

Woolley, Gary. 2011. Reading Comprehension: Assisting Children with Learning Difficulties. New York: Springer. 